\title{
Non-Hodgkins lymphoma in a patient with tracheal bronchus who presented with atypical pneumonia: a diagnostic dilemma
}

\author{
Nnamdi Nwaejike, ${ }^{1}$ Anju Mirakhur, ${ }^{2}$ Jacob Joseph, ${ }^{3}$ Franco Sogliani ${ }^{4}$ \\ ${ }^{1}$ Department of Cardiothoracic Surgery, Northwestern Deanery, Manchester, UK \\ ${ }^{2}$ Department of Respiratory Diseases, Blackpool Victoria Hospital, Blackpool, UK \\ ${ }^{3}$ Department of Neuropathology, Lancashire Teaching Hospitals, Preston, UK \\ ${ }^{4}$ Department of Cardiothoracic Surgery, Blackpool Victoria Hospital, Blackpool, UK \\ Correspondence to Mr Nnamdi Nwaejike, justnnamdi@aol.com
}

\section{DESCRIPTION}

A 47-year-old unemployed man presented with a 2-week history of shortness of breath, dry cough and fever despite normal inflammatory markers and negative blood cultures. There was no weight loss or night sweats. He was a non-smoker and had no other medical history. HIV testing and tumour markers were negative.

Chest x-ray (figure 1A) showed what seemed to be a dense consolidation in the right mid-zone and lower zone. This was confirmed on CT (figure 1F), so wedge biopsies of the right middle and right lower lobes were taken via video-assisted thoracoscopy (VATS). There were no palpable lymph nodes and no evidence of significant mediastinal lyphadenopathy on CT (figure 1C-E). Bronchoscopy at the time of VATS showed a tracheal (pig) bronchus with the right upper lobe bronchus arising separately from the trachea (figure 1B).

Postoperative course was uneventful and he was discharged in good health to the respiratory physicians on day 3. There was no definitive diagnosis following histopathological examination of the lung biopsies. Cultures of the biopsies were negative for any pathogens. With no definite diagnosis, he received nebulisers and oxygen in the interim but subsequently developed seizures requiring intubation and ventilation. MRI, at this time, showed lesions in the brain and he continued to deteriorate and eventually passed away.

Postmortem examination showed high-grade nonHodgkins lymphoma-B-cell type predominantly affecting the brain but also infiltrating the lungs, heart, liver, kidneys and urinary bladder (figure 2).

\section{Learning points}

In patients with known non-Hodgkins lymphoma (NHL) and pulmonary infiltrates, lung biopsy yields specific diagnoses in only $50 \%$ of cases. ${ }^{1}$ Secondary involvement of the lung in patients with lymphoma has an incidence of $25-40 \% .{ }^{2}$ A disappointing reminder of the limitations of lung biopsy as an aid to definite diagnosis for pathology involving the lung parenchyma.

- This patient had symptoms and signs of interstitial lung disease. There were no palpable lymph nodes and no significant mediastinal lyphadenopathy on CT to indicate lymph node biopsy for diagnosis by mediastinoscopy. Unfortunately, this patient had no other symptoms or signs to suggest pathology elsewhere, until seizures led to an MRI showing lesions in the brain. Tumour markers remained negative.

- An atypical presentation of fevers and mass effect (pneumonitis in this case) without other typical symptoms of fatigue, weight loss or night sweats should elicit a high degree of suspicion for lymphoma and appropriate whole body scanning initiated to aid in diagnosis. Even with inconclusive results from lung biopsy, other sources of tissue diagnosis must be sought. Delays in definitive diagnosis can lead to an unfortunate outcome. ${ }^{3}$

Competing interests None.

Patient consent Obtained.

\section{REFERENCES}

1. McCabe RE, Brooks RG, Catterall JR, et al. Open lung biopsy in patients with non-Hodgkin's lymphoma and pulmonary infiltrates. Chest 1989;96:319-24.

2. Ferraro $\mathbf{P}$, Trastek VF, Adlakha $\mathrm{H}$, et al. Primary non-Hodgkin's lymphoma of the lung. Ann Thorac Surg 2000;69:993-7.

3. Atwell SW. Major anomalies of the tracheobronchial tree. Dis Chest 1967:52:611-25. 


\section{BMJ Case Reports}

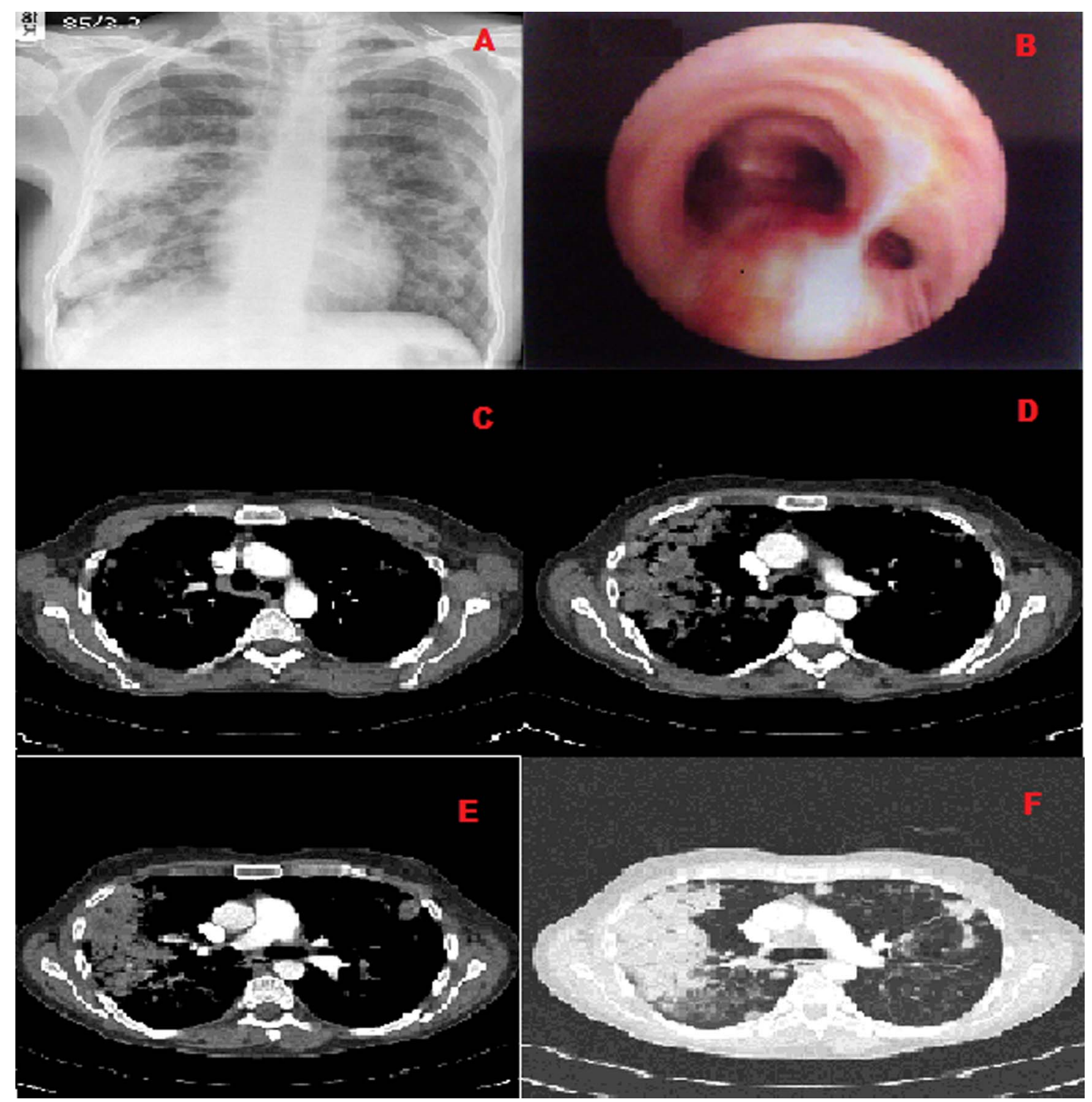

Figure 1 (A) Chest x-ray on presentation. (B) Flexible bronchoscopy showing tracheal bronchus. (C) CT chest (mediastinal window) showing no significant station 2 lymph nodes. (D) CT chest (mediastinal window) showing no significant station 4 lymph nodes. (E) CT chest (mediastinal window) showing no significant station 7 lymph nodes. (F) CT chest (lung window) showing interstitial lung shadowing in the right middle lobe. 


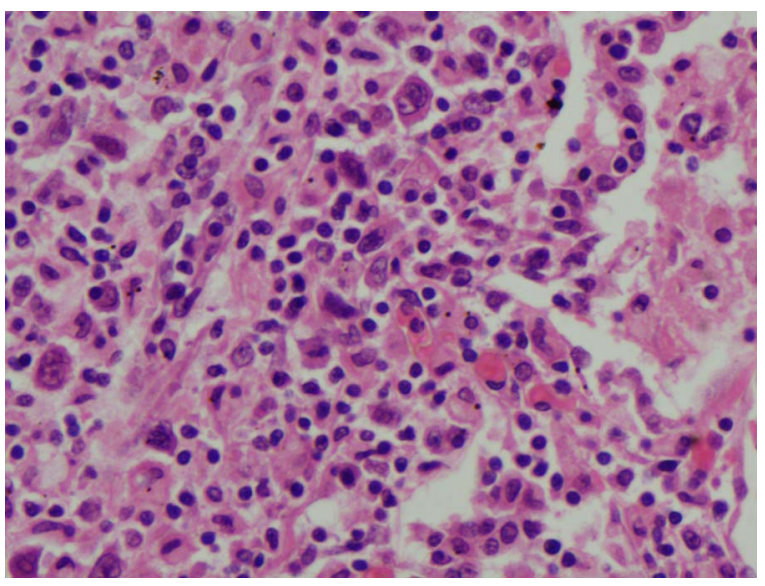

Figure 2 Slide $(\times 40$ magnification) showing lung tissue almost completely replaced by an abnormal lymphoid infiltrate with several larger pleomorphic cells some of which are binucleated. The cells were positive for B-cell markers CD20 and CD79a, making this a diffuse large B-cell lymphoma.

Copyright 2012 BMJ Publishing Group. All rights reserved. For permission to reuse any of this content visit http://group.bmj.com/group/rights-licensing/permissions.

BMJ Case Report Fellows may re-use this article for personal use and teaching without any further permission.

Please cite this article as follows (you will need to access the article online to obtain the date of publication).

Nwaejike N, Mirakhur A, Joseph J, Sogliani F. Non-Hodgkins lymphoma in a patient with tracheal bronchus who presented with atypical pneumonia: a diagnostic dilemma. BMJ Case Reports 2012;10.1136/bcr-2012-006990, Published XXX

Become a Fellow of BMJ Case Reports today and you can:

- Submit as many cases as you like

- Enjoy fast sympathetic peer review and rapid publication of accepted articles

- Access all the published articles

- Re-use any of the published material for personal use and teaching without further permission

For information on Institutional Fellowships contact consortiasales@bmjgroup.com

Visit casereports.bmj.com for more articles like this and to become a Fellow 